\title{
Studies on the Flowers and Stems of Two Cocoyam Varieties: Xanthosoma sagittifolium and Colocasia esculenta
}

Ogukwe CE*, Amaechi PC and Enenebeaku CK

Department of Chemistry, Federal University of Technology, PMB 1526, Owerri, Imo State, Nigeria

\begin{abstract}
Qualitative and quantitative phytochemical composition of the flowers and stem sap of Xanthosoma sagittifolium and Colocasia esculenta were evaluated using standard methods. The result showed that the flowers contain saponins $(6.61 \%$ and $5.50 \%$ respectively for the two species). Alkaloids of 6.22 and $9.80 \%$ respectively were also obtained from the result. Other Phytoconstituents like flavonoids, glycosides, phenols, steroids, and tannins were also evaluated. The proximate analysis revealed that the flowers contain high protein content $(37.87 \%$ and $22.56 \%$ respectively), high moisture content and crude fat. Colocasia esculenta showed high percentage of total carbohydrate. The flowers of the two species of Cocoyam can therefore serve as spices and source of protein in local meals.
\end{abstract}

Keywords: Flowers; Xanthosoma esculenta; Colocasia esculenta; Nutrients; Spices

\section{Introduction}

Cocoyam is a common name for more than one tropical root and vegetable crop belonging to the Arum family (Aroids). Cocoyams are herbaceous perennial plants belonging to the family Araceae and may belong to either the genus Colocasia or the genus Xanthosoma. There are many species of cocoyam in existence, some serve as ornamental plants (e.g., especially Xanthosoma roseum and Colossian antiquorum). While many others exist as wild plants (e.g., Xanthosoma weeksii, Xanthosoma eggersii, and Xanthosoma brasiliense, Colocasia affinis, Colocasia fallax, Colocasia heterochroma, and Colocasia gigantea) as outlined by Brown [1]. Cocoyam species that are cultivated as food crops generally are : Taro (Colocasia esculenta) - old cocoyam and Malanga (Xanthosoma spp.) - new cocoyam These two varieties are grown primarily for their edible roots, although all parts of the plant are edible.

Cocoyam is a herbaceous perennial plant belonging to the family Araceae. It is a root crop cultivated mainly for the edible corms (tuber), although the leaves, petioles and the flowers are used in soup preparation. It constitutes one of the basic food crops of major economic importance in Nigeria. Chukwu et al. [2], stated that it ranks the third after cassava and yam in terms of total production, land area under crop and consumption. The corms can be boiled or baked and consumed in different forms as soup thickeners, pounded foo foo and can also be roasted in fire and can also be prepared as a porridge according to Ajala and Obiechina [3]. The flour of the cocoyam can also be used for the preparation of soups, biscuit, breads and puddings [4].

Reports have shown that cocoyam corm supply easily digestible starch and are known to contain substantial amount of protein, vitamin $\mathrm{C}$, thiamine, riboflavin, niacin and significant amount of dietary fiber. Other part of cocoyam plant such as the leaves, flowers and stems are also consumed especially in sauces, purees, stews and soups, depending on the varieties and the local cultural traditions [5]. Therapeutic benefits of the various part of the plant had also been reported by Tuse et al. [6].

\section{Statement of problem}

Oral History related that during the 19th century and the early 20th century, non-urban dwellers used dried flower of cocoyam as food additive as spices or seasoning. This dried flower of cocoyam was used in preparing local soups and dishes. This was used to improve the quality and the nutritional value of the meal thereby making it palatable. Thus, this dried flower of cocoyam was used in place of modern day synthetic spices or seasoning. This research work has therefore been designed to evaluate the probable nutrients of the flowers and the phytoconstituents of the stem sap of two varieties of cocoyam- Colocasia esculenta and Xanthosoma sagittifolium.

\section{Materials and Methods}

\section{Sample collection and preparation}

The Cocoyam flowers and stem were collected from private farms at Ogwa in Mbaitolu, Ihiagwa and Nekede all in Imo State, Nigeria. The harvested plant materials were identified and authenticated by Professor AE Ibe Department of Crop Science Federal University of Technology Owerri (FUTO), and were properly labeled as experimental samples. The samples were air dried at room temperature, grounded to fine powder (using a mill) and stored in air tight containers for laboratory analysis (Figures 1 and 2).

\section{Extraction of the plant samples}

The powdered samples were extracted with $95 \%$ ethanol in Soxhlet extractor for a period of 4 hours. The extracts were concentrated on a water bath and weighed portions were used for phytochemical screening.

\section{Proximate analysis}

Proximate composition (moisture, ash, crude protein, crude fat, crude fiber) of the samples were determined in triplicate using Association of Official Analytical Chemists (AOAC) approved methods [7]. Moisture content of the sample was determined by weighing $5 \mathrm{~g}$ of the sample and drying in an oven at $105^{\circ} \mathrm{C}$ to constant

*Corresponding author: Cynthia E Ogukwe, Department of Chemistry, Federal University of Technology, PMB 1526, Owerri, Imo State, Nigeria, Tel: +2348037059296; E-mail: cynthiaogukwe94@yahoo.com

Received April 05, 2017; Accepted April 18, 2017; Published April 24, 2017

Citation: Ogukwe CE, Amaechi PC, Enenebeaku CK (2017) Studies on the Flowers and Stems of Two Cocoyam Varieties: Xanthosoma sagittifolium and Colocasia esculenta. Nat Prod Chem Res 5: 263. doi: 10.4172/2329-6836.1000263

Copyright: (c) 2017 Ogukwe CE, et al. This is an open-access article distributed under the terms of the Creative Commons Attribution License, which permits unrestricted use, distribution, and reproduction in any medium, provided the original author and source are credited. 


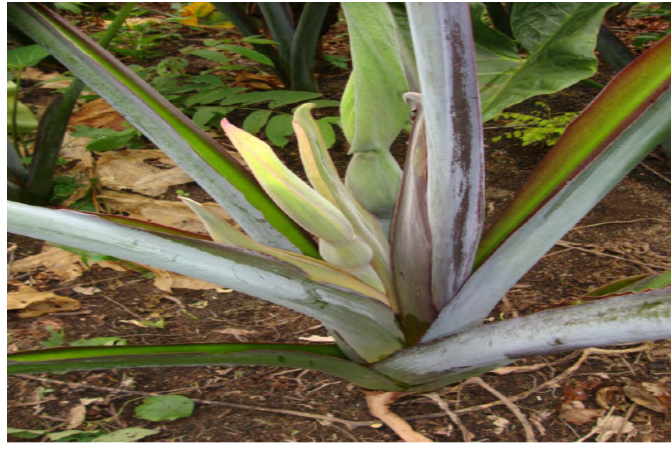

Figure 1: Xanthosoma sagittifolium flower.

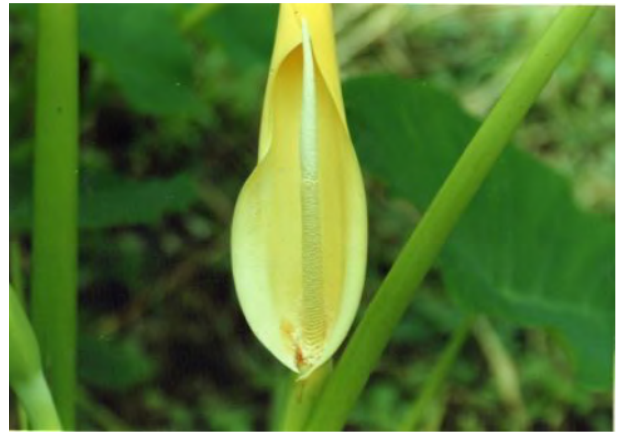

Figure 2: Colocasia esculenta flower.

weight. The loss in weight of the sample was calculated as moisture content. Ash content was determined as percentage ash content by incineration of $5 \mathrm{~g}$ of the samples in a muffle furnace at $550^{\circ} \mathrm{C}$ for 2.5 hours. The weight of the residual ash was calculated as a percentage of the $5 \mathrm{~g}$ that was burnt. Crude protein was determined by Kjeldahl method. Fiber content was determined by boiling $5 \mathrm{~g}$ of the sample in a mineral acid for 30 minutes, also in $1.25 \% \mathrm{NaOH}$ solution for another 30 minutes and then filtered. The residue was washed, dried in an Oven and incinerated at $600^{\circ} \mathrm{C}$ in muffle furnace for 2 hours. Loss in weight on incineration was recorded as the fiber content. Crude fat was quantified from dried samples by Soxhlet extraction method using $\mathrm{n}$-hexane as solvent and percentage fat calculated on dry weight bases [8]. Carbohydrate was estimated by difference (AOAC).

\section{Qualitative phytochemical analysis}

Qualitative phytochemical analysis was done with the following methods; Alkaloids analyzed using Mayer's test method, Glycosides using Keller killiani method, Phenols using ferric chloride test method, Saponins using froth test method, Tannins using ferric chloride test method, Steroids using libermann-burchard test method.

\section{Quantitative phytochemical analysis}

Quantitative phytochemical analysis was done with the following methods; Saponins was done using method described by Obadoni and Ochuko [9]. Flavonoids and Alkaloids were determined as described by Harborne [10]. Tannins were obtained by using the method described by Pearson [11]. Glycosides were determined by AOAC (1984) method.

\section{Statistical data analysis}

The obtained results of analysis were expressed as the mean \pm standard deviation (S.D). The statistical analysis was carried out using t-test method. Difference between the means was considered to be significant at $95 \%$ confidence limit. Difference in the mean of the treatments at $\mathrm{p}<0.05$ were considered significant.

\section{Results and Discussion}

The result of the proximate composition of the flowers of Xanthosoma sagittifolium and Colocasia esculenta is shown in Table 1. The moisture content; Xanthosoma sagittifolium (16.1\%) and Colocasia esculenta (16.35\%) obtained from the two species of cocoyam gave a relatively high value when compared to FAO standard for spices from flower which is $5-11 \%$ and also relatively high when compared to USDA standard for spices which is $8.46 \%$. These values were also significantly higher than the moisture content of spices like garlic, ginger and pepper which has $4.55 \%, 6.37 \%$ and $5.70 \%$ respectively as revealed by Otunola et al. [12]. The percentage crude protein is an indication of the amount of amino acids present in the sample. Xanthosoma sagittifolium showed significantly a very high percentage of crude protein of $37.87 \%$ as against the value of Colocasia esculenta that has $22.56 \%$. The two values show that the flowers of the two cocoyam are protein rich. These results are in agreement with the report of Hussam et al. [13] which reveals that the protein content of the corm of Xanthosoma sagittifolium (tannia) is significantly higher that the value of other tuber crops. Standal [14] also reported that Xanthosoma sagittifolium contains more amino acids than cassava, yam and sweet potatoes. According to the proximate result of Nwinuka et al. [15], the percentage crude protein of four spices; ginger, garlic, onions and Ashanti pepper, showed 8.58\%, $17.35 \%$, $10.45 \%$ and $12.50 \%$ respectively which are significantly lower than the values of Xanthosoma sagittifolium and Colocasia esculenta respectively. However, these values are higher than the USDA standard value for spices which is $6.09 \%$. Ash content is the residue remaining after all the moisture has been removed as well as organic materials. Ash content is a reflection of mineral content present. High ash content will imply high mineral content and consequently will be very nutritious. From Table 1, Xanthosoma sagittifolium has an ash content of $6.23 \%$ as against Colocasia esculenta which is $6.61 \%$. Thus, Colocasia esculenta has more mineral content than Xanthosoma sagittifolium. This is in agreement with the result of Njoku et al. [16] which showed that Colocasia esculenta always has higher percentage of ash content than Xanthosoma sagittifolium. According to Okonkwo et al. [17], the ash content of four spices such as nutmeg, rosemary, African nutmeg (ehuru) and Ashanti pepper gave 9.84\%, $11.78 \%$, $10.49 \%$, and $6.33 \%$ respectively. The value of Ashanti pepper is closed to the values of the cocoyam flowers while others are relatively higher. However, the FAO standard for spices from flowers is $4.7-8 \%$.

\begin{tabular}{|c|c|c|}
\hline Parameter & \multicolumn{2}{|c|}{ Values (\%) } \\
\hline & $\begin{array}{c}\text { Xanthosoma } \\
\text { sagittifolium }\end{array}$ & Colocasia esculenta \\
\hline Moisture content & $16.1 \pm 0.1$ & $16.35 \pm 0.02$ \\
\hline Crude protein & $37.87 \pm 0.02$ & $22.56 \pm 0.015$ \\
\hline Ash content & $6.23 \pm 0.02$ & $6.61 \pm 0.04$ \\
\hline Crude fat & $13.13 \pm 0.045$ & $14.05 \pm 0.01$ \\
\hline Fiber content & $12.92 \pm 0.026$ & $15.32 \pm 0.025$ \\
\hline Total carbohydrate & $13.75 \pm 0.03$ & $25.11 \pm 0.03$ \\
\hline
\end{tabular}

Table 1: Result of the proximate analysis of the two-cocoyam species.Values expressed as Mean \pm SD. 
Fat content of samples is an indication of the presence of number of lipid substances. Colocasia esculenta showed greater amount of fat content of $14.05 \%$ while Xanthosoma sagittifolium has $13.13 \%$. These values are greater than the fat content of the corm of Xanthosoma sagittifolium and Colocasia esculenta in Tanzania and Uganda which had values $0.43 \%$ and $0.44 \%$ respectively as reported by Ndabikunze et al. [18]. Fat content of nutmeg, rosemary spice gave $11.50 \%$ and $14.30 \%$ respectively as shown by Okonkwo et al. [17]. However, the USDA nutrient database standard of fat content for spices is $8.69 \%$ [19]. The crude fiber represents the combustible organic residue that is left after other biomolecules have been removed. These can be referred to as the materials that are indigestible in human and animal organism. Colocasia esculenta showed a greater percentage of crude fiber content of $15.32 \%$ as against Xanthosoma sagittifolium that has $12.92 \%$. These values are relatively high when compared to the values obtained by Odebunmi et al. [20], in the proximate analysis of garlic $(0.73 \%)$, ginger $(2.93 \%)$ and pepper $(2.61 \%)$ but are lower than the fiber content percentage of their leaves; Xanthosoma sagittifolium (17.17\%), Colocasia esculenta (17.41\%) as reported by Olaleye et al. [21]. The values for the crude fiber of nutmeg, rosemary spice and African nutmeg are $12.52 \%, 14.26 \%$ and $13.66 \%$ respectively as shown by Okonkwo et al. [17]. The USDA nutrient standard of crude fiber for spices is $21.6 \%$. The total carbohydrate is the portion or composition remaining after moisture, crude protein, ash, fat and fiber compositions has been removed. It is an indication of energy giving ability of the sample. Colocasia esculenta showed significantly higher amount of total carbohydrate of $25.11 \%$ as against Xanthosoma sagittifolium that has $13.75 \%$. These values are significantly smaller when compared with the values of four spices; ginger (72.84\%), garlic (73.03\%), onions (76.71\%), Ashanti pepper (67.59\%) as reported by Nwinuka et al. The total carbohydrate of another three spices; nutmeg (41.57\%), rosemary (45.84\%) and African nutmeg (44.84\%) as shown by Okonkwo et al. are also relatively high. These are represented in the chart in Figure 3.

Phytochemical analysis showed that alkaloids, flavonoids, glycosides, phenols, saponins, steroid, tannins were all present in the flower extract of Xanthosoma sagittifolium with phenols deeply present. Alkaloids, saponins and flavonoids were slightly present. Tannins and steroids were very slightly present. The stem extract of Xanthosoma sagittifolium showed the presence of alkaloids, flavonoids, glycosides, phenols, saponins, steroid, and tannins. The analysis showed that phenols, tannins and saponins, were slightly present whereas alkaloids, flavonoids, glycosides and steroids were very slightly present Table 2 .

The analysis shows that alkaloids, flavonoids, glycosides, phenols,

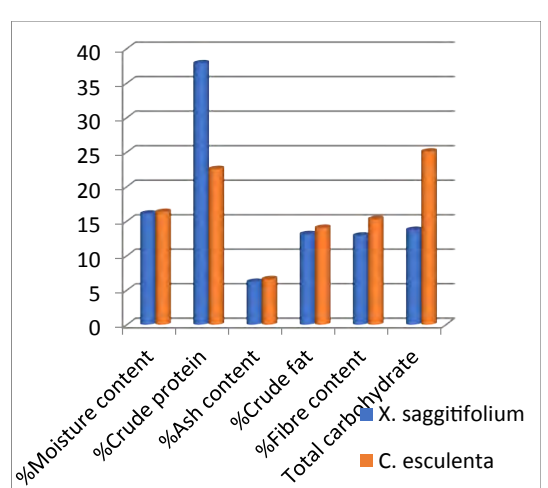

Figure 3: Bar chart for the Proximate analysis of Xanthosoma sagittifolium and Colocasia esculenta flowers. saponins, steroid, tannins where are present. In the flower extract, phenols were deeply present. Alkaloids, flavonoids, saponins and tannins where detected slightly whereas glycosides and steroids were very slightly present. The stem extract of colocasia esculenta showed the presence of alkaloids, flavonoids, glycosides, phenols, saponins, steroid, and tannins. Flavonoids, glycosides and steroids where very slightly detected. Tannins were deeply present whereas alkaloids, phenols, and saponins were slightly detected Table 3.

The results of the quantitative analysis of Xanthosoma sagittifolium flower gave $6.61 \%$ saponins, $1.32 \%$ flavonoids, $6.20 \%$ alkaloids, $0.50 \%$ tannins and $1382.5 \mathrm{ppm}$ of glycosides. The value of the alkaloids are relatively high while the value for flavonoids and tannins are relatively low when compared to the results of Raney et al. [22] in the analysis of nutmeg which has alkaloid (3.17\%), flavonoids $(4.89 \%)$ and tannins (2.23\%). Analysis of Colocasia esculenta flower revealed that it contains $5.50 \%$ saponins, $3.20 \%$ flavonoids, $9.80 \%$ alkaloids, $1.26 \%$ tannins and $1372.5 \mathrm{ppm}$ glycosides. The values of saponins and glycosides in Colocasia esculenta are comparatively smaller than the values in Xanthosoma sagittifolium. Statistically, there is a significant difference between these values at $\mathrm{P}<0.05$. Whereas the values of flavonoids, alkaloids and tannins are higher in Colocasia esculenta than in Xanthosoma sagittifolium. At $\mathrm{P}<0.05$, there is also a significant difference between the two samples Table 4 . These are better expressed in the chart at Figure 4.

Analysis of the stem sap of Xanthosoma sagittifolium revealed that the saponins content is $4.71 \%$, flavonoids is $0.51 \%$, alkaloid is $4.31 \%$, tannin is $1.25 \%$, glycoside is $527.5 \mathrm{ppm}$. These values are relatively high when compared to the result presented by Olaleye et al. on the analysis of the leaves of Xanthosoma sagittifolium in which the saponins is $1.44 \%$, tannin is $0.47 \%$, alkaloids are $0.02 \%$. Analysis of the stem of Colocasia esculenta as shown in Table 5 shows that

\begin{tabular}{|c|c|c|}
\hline Parameter & \multicolumn{2}{|c|}{ Inference } \\
\hline & Flower & Stem \\
\hline Alkaloids & ++ & + \\
\hline Flavonoids & ++ & + \\
\hline Glycosides & + & + \\
\hline Phenols & +++ & ++ \\
\hline Saponins & ++ & ++ \\
\hline Steroids & + & + \\
\hline Tannins & + & ++ \\
\hline
\end{tabular}

$(+++)=$ deeply present, $(++)=$ slightly present, $(+)=$ very slightly present

Table 2: Qualitative phytochemicals analysis of Xanthosoma sagittifolium flower and stem. 
Citation: Ogukwe CE, Amaechi PC, Enenebeaku CK (2017) Studies on the Flowers and Stems of Two Cocoyam Varieties: Xanthosoma sagittifolium and Colocasia esculenta. Nat Prod Chem Res 5: 263. doi: 10.4172/2329-6836.1000263

\begin{tabular}{|c|c|c|}
\hline \multirow{2}{*}{ Parameter } & \multicolumn{2}{|c|}{ Inference } \\
\cline { 2 - 3 } & Flower & Stem \\
\hline Alkaloids & ++ & ++ \\
\hline Flavonoids & ++ & + \\
\hline Glycosides & + & + \\
\hline Phenols & +++ & ++ \\
\hline Saponins & ++ & ++ \\
\hline Steroids & + & +++ \\
\hline Tannins & ++ & + \\
\hline
\end{tabular}

Table 3: Qualitative phytochemicals analysis of Colocasia esculenta flower and stem

\begin{tabular}{|c|c|c|}
\hline Parameter & Flower & Stem \\
\hline Saponins & $6.61 \pm 0.015$ & $4.71 \pm 0.02$ \\
\hline Flavonoids & $1.32 \pm 0.02$ & $0.51 \pm 0.012$ \\
\hline Alkaloids & $6.20 \pm 0.02$ & $4.31 \pm 0.02$ \\
\hline Tannins & $0.50 \pm 0.01$ & $1.25 \pm 0.015$ \\
\hline Glycosides & $1382.5 \pm 0.3$ & $527.5 \pm 0.4$ \\
\hline
\end{tabular}

Values expressed as Mean \pm SD

Table 4: Quantitative phytochemical analysis of Xanthosoma sagittifolium.

\begin{tabular}{|c|c|c|}
\hline Parameter & Flower & Stem \\
\hline Saponins & $5.50 \pm 0.03$ & $4.20 \pm 0.02$ \\
\hline Flavonoids & $3.20 \pm 0.015$ & $1.80 \pm 0.012$ \\
\hline Alkaloids & $9.80 \pm 0.01$ & $5.50 \pm 0.02$ \\
\hline Tannins & $1.26 \pm 0.01$ & $1.16 \pm 0.03$ \\
\hline Glycosides & $1372.5 \pm 0.3$ & $865.8 \pm 0.25$ \\
\hline
\end{tabular}

Values expressed as Mean \pm SD

Table 5: Quantitative phytochemical analysis of Colocasia esculenta.

the stem contains $4.20 \%$ saponins, $1.80 \%$ flavonoids, 5.50 alkaloids, $1.16 \%$ tannins and $865.8 \mathrm{ppm}$ glycosides. The saponins, tannin and alkaloids contents of the stem of Colocasia esculenta are comparatively higher than the value obtained from the leaves as reported by Olaleye et al. in which saponins is $1.50 \%$, tannin is $0.76 \%$, alkaloid is $0.75 \%$. Statistically, at $\mathrm{P}<0.05$, there is significant difference between the values obtained for Xanthosoma sagittifolium and Colocasia esculenta. These are better expressed in the chart at Figure 5.

\section{Conclusion}

The moisture content of the two flowers was relatively higher than the FAO and USDA nutrient standards [23]. When compared to the moisture content of spices like ginger, garlic and certain pepper they were higher making them unsuitable and consequently will have a very short shelve life. The protein content was also very high when compared to the protein content of known spices and the USDA nutrient standard. High protein means high amino acid which might really be unsuitable. The ash content which is a reflection of the mineral content is within the standard of FAO and in agreement with the ash content of spice like Ashanti pepper. The crude fiber is lower than the USDA nutrient standard for crude fiber. And the total carbohydrate is lower than the carbohydrates of many of the known spices like onions, ginger, garlic, Ashanti pepper, nutmeg, rosemary and African nutmeg. These factors have made the flowers of Xanthosoma sagittifolium and Colocasia esculenta unsuitable to be packaged and marketed as a standard spice.

Qualitative and quantitative phytochemical analysis revealed that the flowers of the two cocoyam varieties are rich in phenolic

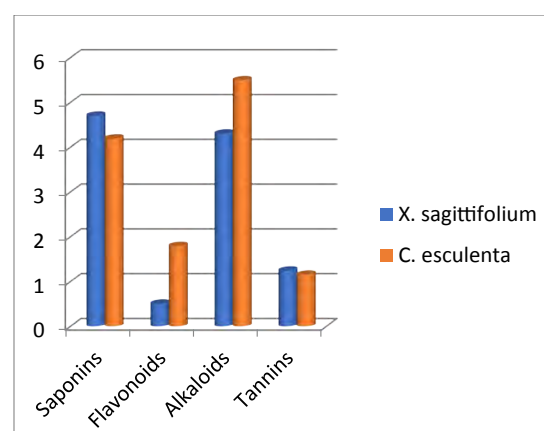

Figure 5: Bar chart of quantitative phytochemical analysis of the stem extract of Xanthosoma sagittifolium and Colocasia esculenta.

compounds, saponins and alkaloids. But contain very small amount of glycosides and steroids. While the stems of the two cocoyam varieties contain more of saponins, alkaloids and tannins.

\section{References}

1. Brown DA (2000) Plants of the Arum Family. Timber Press, Oregon, p: 250.

2. Chukwu GO, Nwosu KI (2008) Cocoyam rebirth. The renaissance of giant crop. Paper presented at the 17th Annual conference of Nigeria rural sociological Association at NRCRI Umudike. p: 11.

3. Ajala AA, Obiechina OC (1987) Social-economic and cultural importance of cocoyam. A case study of Nsuka Agricultural zone of Anambra (Now Enugu state) proceeding of the 1st National workshop on cocoyam. August 16th -21st NRCRI, Umudike, Nigeria.

4. Niba LL (2003) Processing effects on the susceptibility of starch in some dietry starch sources. International Journal of Food Science and Nutrition 54: 97-109.

5. Ejoh AR, Mbiapo FT, Fokon E (1996) Nutrient composition of the leaves of Colocasia esculenta and the fruits of Solanum melongena. Plant food for human nutrition 49: 107-112.

6. Tuse TA, Harle UN, Bore VV (2009) Hepatoprotective activity of Colocasia antiquorom against experimentally induced liver injury in rats. Malaysian journal of pharm Sc 7: 99-112.

7. AOAC (2000) Official Methods of Analysis. 15th edn., Association of Officia Analytical chemists, Washington DC, Brown, Deni. Aroids. Plants of the Arum Family. Timber Press, Oregon, p: 250.

8. Subbulakshmi G, Chitra L (1996) Method for determining nutrients in foods: A critical appraisal. J Food Sci Technol 33: 267-284.

9. Obadoni BO, Ochuko PO (2001) Phytochemical studies and comparactive efficacy of the crude extracts of some haemostatics plants in Edo and Delta states of Nigeria. Global J of Appl Sc 8: 203-208.

10. Harborne JB (1973) Phytochemical methods of extraction. COX and Wymann Ltd. London, pp: 52-55, 66-70.

11. Pearson D (1976) Chemical analysis of foods. 7th edn. Churchill Livingston Edinburg.

12. Otunola GA, Oloyede OB, Oladiji AT, Afolayan AJ (2010) Comparative analysis of the chemical composition of three spices commonly consumesd in Nigeria. African $\mathrm{J}$ of biotechnology 41: 6927-6931.

13. Hussam M, Norton G, Neale RJ (1984) Composition and nutritive value of cormel colocasia esculenta. Journal Science food agric 35: 112-117.

14. Standal BR (1983) Nutritive value of Taro. A review of colocasia esculenta and it's potential. pp: 141-145.

15. Nwinuka NM, Ibeh GO, Ekeke GI (2005) Proximate composition and levels of some toxicants in four commonly consumed spices. J Appl Sc Environmental Mgt 9: 150-155.

16. Njoku PC, Ohia CC (2007) Spectrophometric Estimation Studies of Mineral Nutrient in Three Cocoyam Cultivars. Pakistan J Nutrition 6: 616-619.

17. Okonkwo C, Ogu A (2014) Nutritional evaluation of some selected spices commonly used in the south-Eastern part of Nigeria. $\mathrm{J}$ of Biology Agriculture and Health Care, p: 4. 
Citation: Ogukwe CE, Amaechi PC, Enenebeaku CK (2017) Studies on the Flowers and Stems of Two Cocoyam Varieties: Xanthosoma sagittifolium and Colocasia esculenta. Nat Prod Chem Res 5: 263. doi: 10.4172/2329-6836.1000263

18. Ndabikunze BK, Talwana HA, Mongi RJ, Issa-Zacharia A, Serem AK, et al (2011) Proximate and mineral composition of Cocoyam (Colocasia esculenta and Xanthosoma sagittifolium) grown along the lake victoria basin in Tanzania and Uganda. African Journal of food Science 5: 248-254.

19. United State Department of Agriculture (USDA) National nutrient database for standard reference release. p: 27.

20. Odebunmi EO, Oluwaniyi OO, Bashim MO (2009) Comparative proximate analysis of some food condiments. Journal of Appl Sci Research 6: 272-274.
21. Olaleye LD, Owolabi BJ, Adesin AO, Isiaka AA (2013) Chemical composition of red and white cocoyam leaves. International Journal of Sci and Research, p: 2.

22. Raney AT, Krishnakumari S (2015) Phytochemical quantification of primary and secondary metabolites of Myristica fragrans $(\mathrm{H})$ ethanolic seed extract. Int Journal Pharm Bio Sc 6: 1046-1053.

23. Food and Agricultural Organisation (1997) FAO food and nutritive paper Manual of food quality control. 